\title{
Diagnostic performance of the ARCHITECT C-Peptide immunoassay
}

\author{
Jan Schultess ${ }^{1, *}$, Cathelijne van Duren ${ }^{2}$, Mike \\ Martens ${ }^{2}$, Marta Costa ${ }^{3}$, Teresa Llop ${ }^{3}$, Teresa \\ Martí $^{3}$, Martina Eppinger ${ }^{1}$, Michael Hausmann $^{1}$, \\ Wolfgang Krack ${ }^{1}$ and Jens Dhein ${ }^{1}$ \\ ${ }^{1}$ Abbott GmbH and Co. KG, Wiesbaden, Germany \\ ${ }^{2}$ Future Diagnostics BV, Wijchen, The Netherlands \\ ${ }^{3}$ Biokit S. A., Lliçà d'Amunt, Spain
}

\begin{abstract}
Background: Measurement of C-peptide under standardized conditions provides a sensitive and wellestablished assessment of $\beta$-cell function. We describe the analytical and clinical validation of an automated, microparticle-based chemiluminescent immunoassay method. The assay is designed to measure C-peptide in human serum, plasma and urine.

Methods: Assay performance characteristics such as precision and recovery were measured according to protocols established by the Clinical Laboratory Standards Institute (CLSI). A reference range study was conducted. Analytical sensitivity and specificity, interfering substances, recovery, and linearity studies were performed. Method comparison, against the ADVIA Centaur C-Peptide assay (Siemens), was evaluated with clinical specimens from patients with abnormal insulin secretion.
\end{abstract}

Results: The detection limit for this assay was 0.01 $\mathrm{ng} / \mathrm{mL}$. Functional sensitivity (inter-assay imprecision $\leq 20 \%$ ) was $0.015 \mathrm{ng} / \mathrm{mL}$ at a coefficient of variation (\%CV) of $11.2 \%$. Total imprecision was below $6.5 \%$ $\mathrm{CV}$. The assay was linear upon dilution. Comparison with the ADVIA Centaur C-Peptide assay yielded a correlation coefficient $(r)$ of 0.99 .

Conclusions: The ARCHITECT C-Peptide assay measures C-peptide rapidly, accurately, and precisely in human serum, plasma and urine. It provides useful improvements for $\beta$-cell function testing and for evaluating the clinical status of a patient in combination with other diabetes markers.

Clin Chem Lab Med 2009;47:834-41.

Keywords: analytical performance; Architect; C-peptide; diabetes; insulin.

*Corresponding author: Jan Schultess, Abbott GmbH and Co. KG, Max-Planck-Ring 2, 65205 Wiesbaden-Delkenheim, Germany

Phone: + 49(0)6122-58-2943, Fax: + 49(0)6122-58-1473

E-mail: jan.schultess@abbott.com

Received December 19, 2008; accepted April 13, 2009;

previously published online June 4, 2009

\section{Introduction}

C-peptide is a single chain polypeptide consisting of 31 amino acids. It connects the $A$ and $B$ chains of insulin in the precursor molecule proinsulin, which is stored in secretory granules of the pancreatic $\beta$-cell (1-3). C-peptide facilitates the formation of the correct secondary and tertiary structure of the hormone during insulin biosynthesis $(3,4)$. C-peptide and insulin are secreted in equimolar amounts; however, C-peptide does not undergo significant hepatic metabolism. Instead, C-peptide is eliminated by the kidney and therefore, persists longer in the peripheral circulation, with a half-life $>30 \mathrm{~min}$. Insulin shows greater fluctuations in concentrations compared to $\mathrm{C}$-peptide and has a much shorter half-life of $\sim 5 \mathrm{~min}$ (5-7). Measurement of $\mathrm{C}$-peptide more accurately reflects pancreatic insulin secretion rates compared with insulin. Also, C-peptide concentrations are independent of exogenous insulin administration and are not subject to interference from insulin autoantibodies induced by therapy with insulin.

$\mathrm{C}$-peptide is excreted in the urine and determination of the $24 \mathrm{~h}$ urinary excretion of $\mathrm{C}$-peptide provides a useful monitor of mean $\beta$-cell insulin secretion. In addition, measurement of C-peptide in urine is preferred if frequent analyses have to be performed in children.

C-peptide is used as a test of $\beta$-cell function in human subjects for a variety of conditions including type I diabetes, hypoglycemia and surreptitious self-administration of insulin (8-10). A low C-peptide concentration is expected if insulin secretion is diminished as in insulin-dependent diabetes [type-1 diabetes, latent autoimmune diabetes of adults (LADA)]. Increased C-peptide concentrations may be found when $\beta$-cell activity is increased as in hyperinsulinism and insulinomas (11). The molar ratio of C-peptide/ insulin can be considered an estimation of hepatic clearance, since insulin metabolism is impaired in liver insufficiency. This results in an abnormally large proportion of insulin relative to C-peptide in the peripheral circulation (12).

We evaluated the performance characteristics of the C-peptide immunoassay for the ARCHITECT $i$ System.

\section{Materials and methods}

\section{C-peptide assay}

C-peptide was measured in samples with the ARCHITECT CPeptide assay (Biokit S.A., Lliçà d'Amunt, Spain) according to the manufacturer's instructions. The ARCHITECT C-Pep- 
tide assay is a two-step immunoassay for the quantitative determination of $\mathrm{C}$-peptide in human serum, plasma and urine. It uses chemiluminescent microparticle immunoassay technology, with a time to first result of $29 \mathrm{~min}$ and a throughput of 200 specimens/h. The assay is standardized against the WHO International Reference Reagent (IRR) for C-peptide of human insulin for immunoassay, IRR, code 84/ 510, established 1986, from the National Institute for Biological Standards and Control (NIBSC) (13).

In the first step, sample, assay diluent, and anti-C-peptide coated paramagnetic microparticles are combined. C-peptide present in the sample binds to anti-C-peptide coated microparticles, forming an antigen-antibody complex. After washing, anti-C-peptide acridinium-labeled conjugate is added to create a reaction mixture in the second step. Following another wash cycle, pre-trigger and trigger solutions are added to the reaction mixture. The resulting chemiluminescent reaction is measured as relative light units (RLUs). A direct relationship exists between the amount of $\mathrm{C}$-peptide in the sample and the RLUs detected by the ARCHITECT $i$ System optics. Results are calculated automatically based on the previously established calibration curve. The instrument automatically predilutes urine specimens.

The system was calibrated according to the manufacturer's instructions every 30 days throughout the course of the study. The calibration curve ranged from $0.00 \mathrm{ng} / \mathrm{mL}$ to $30.00 \mathrm{ng} / \mathrm{mL}$.

Calculations were performed using "Analyse-it" software package (version 1.73 or higher) (14) and SAS programming code (version 6.12 or higher) (15).

\section{Specimens}

Serum/plasma specimens for sample type and specimen stability studies: Whole blood specimens from Biobanc (Hospital Sant Joan, Reus, Spain) were collected in the following anticoagulant tubes: serum separator tube, potassium EDTA, sodium citrate, sodium heparin, ammonium heparin, lithium heparin, lithium heparin separator tube, sodium fluoride/ potassium oxalate.

Serum samples used for the method comparison study were obtained from Labor Limbach (Heidelberg, Germany). Frozen samples were obtained from Partnerschaftspraxis für Laboratoriumsmedizin und Mikrobiologie (Hameln, Germany) for use in a method comparison study.

Blood from random blood donors was received from Centre de Transfusió I Banc de Teixits de Catalunya (Barcelona, Spain).

For evaluation of the reference range, apparently healthy, fasting (i.e., 10-12 h prior to the blood draw) adult blood donor population sera were collected from Bad Kreuznach (Dr. med. Axel Buhtz, Germany; 23 females and 77 males, aged 23-63 years) and University of Mainz (Germany; 23 specimens, no information on gender, aged 31-60 years).

Urine specimens: Frozen urine samples were received from Canisius-Wilhelmina Hospital (CWZ Nijmegen, The Netherlands; 50 females and 50 males aged 1-89 years). Twenty-four hours urine specimens were collected without preservatives into a clean, single container and stored at $2^{\circ} \mathrm{C}-8^{\circ} \mathrm{C}$ during the collection process. Urine specimens were obtained from Bioscientia (Ingelheim, Germany; 30 females and 20 males, aged $18-53$ years), Bad Kreuznach (Germany; 30 males, aged 18-63 years) and University of Mainz (Germany; 50 specimens, no information on gender, aged 18-68 years).

Finally, additional urine specimens were collected at Future Diagnostics (Wijchen, The Netherlands; 27 females and 23 males, aged 23-60 years) and Biokit (Lliçà d'Amunt, Spain; 10 females, aged $24-48$ years).

\section{Expected values}

Reference intervals were evaluated based on guidance from CLSI document C28-A2 (16). Serum specimens and $24 \mathrm{~h}$ urine specimens were measured using the ARCHITECT CPeptide assay. Reference intervals for serum and urine specimens were calculated using the 97.5 th and 2.5 th percentile values.

\section{Sensitivity}

Analytical sensitivity Analytical sensitivity was determined as the concentration corresponding to the signal obtained at 2 SDs from the mean of the signal of a sample with a Cpeptide concentration of zero. Twenty replicates of Calibrator $\mathrm{A}$, containing no $\mathrm{C}$-peptide, were measured and the mean and standard deviation (SD) determined. The apparent concentration at $2 \mathrm{SDs}$ above the mean was calculated.

LoB, LoD, LoO Limit of blank (LoB), limit of detection (LoD) and limit of quantitation (LoQ) were determined based on CLSI document EP17-A (17).

The LoB represents the highest value (concentration) that would be expected for a zero-concentration sample. Fifteen replicates ( 3 replicates, during 5 days) of four different lots of Calibrator A, containing no C-peptide, were assayed. The measured values were sorted in ascending order and the $95 \%$ quartile was calculated.

The LoD is the lowest concentration for a sample that can be detected with a $95 \%$ probability as being greater than a blank. The LoD was established using the formula, $\mathrm{LoD}=\mathrm{LoB}+1.65 \mathrm{SD}_{\mathrm{s}}$, where $\mathrm{SD}_{\mathrm{s}}$ are the pooled standard deviations (SD) of four serum samples containing low C-peptide concentrations (sample 1: $0.00152 \mathrm{ng} / \mathrm{mL}$, sample 2: $0.00304 \mathrm{ng} / \mathrm{mL}$, sample 3: $0.00608 \mathrm{ng} / \mathrm{mL}$, sample 4: $0.01520 \mathrm{ng} / \mathrm{mL}) . \mathrm{SD}_{\mathrm{s}}=\left(\left[\mathrm{SD}_{1}{ }^{2}+\mathrm{SD}_{2}{ }^{2}+\mathrm{SD}_{3}{ }^{2}+\mathrm{SD}_{4}{ }^{2}\right] / 4\right)^{0.5}$.

The LoO is defined as the lowest amount of analyte in a sample that can be quantitatively measured with acceptable precision and trueness. LoO was determined by preparing a set of multiple dilutions of Calibrators $C(0.24 \mathrm{ng} / \mathrm{mL})$ and $A$ $(0 \mathrm{ng} / \mathrm{mL}$ ). This resulted in theoretical C-peptide concentrations of $0.096,0.072,0.048,0.036$ and $0.024 \mathrm{ng} / \mathrm{mL}$. The diluted Calibrators were analyzed 8 times (duplicates of 4 independent dilutions) in 5 runs $(n=40)$. The difference between the mean of the replicates and the accepted reference value was used as an estimate of bias and the total error. This was calculated as: bias $+2 \quad \mathrm{SD}_{\mathrm{s}}$, where $\mathrm{SD}_{\mathrm{s}}{ }^{2}=7 \times\left(\mathrm{SD}_{\mathrm{s} 1}{ }^{2}+\cdots+\mathrm{SD}_{\mathrm{s} 5}{ }^{2}\right) / 35$.

Functional sensitivity A series of four samples with low Cpeptide concentrations was prepared and analyzed at 10 different time points. The minimum C-peptide concentration with a total percent coefficient of variation $(\% \mathrm{CV}) \leq 20 \%$ was determined.

Precision A study was performed with the ARCHITECT CPeptide assay, based on CLSI document EP5-A2 (18).

Precision was evaluated using two instruments and a panel of nine samples, consisting of low control, medium control and high control, three serum specimens and three urine specimens. The panel was tested across two reagent lots in two replicates, 2 times/day, for 20 days. 


\section{Linearity and recovery}

Dilution linearity A linearity study was performed using pooled serum samples with C-peptide values ranging from $0.63 \mathrm{ng} / \mathrm{mL}$ to $15.66 \mathrm{ng} / \mathrm{mL}$. These samples were diluted manually using ARCHITECT $i$ Multi-Assay Manual Diluent (LN 7D82) to achieve concentrations ranging from $90 \%$ to $50 \%$ of the original C-peptide value. To ensure that the highest concentration range of the assay was covered, dilution of Calibrator $F(30.00 \mathrm{ng} / \mathrm{mL})$ was also performed.

In addition, a linearity study was performed using urine samples with C-peptide values that ranged from $6.80 \mathrm{ng} / \mathrm{mL}$ to $284.48 \mathrm{ng} / \mathrm{mL}$. These samples were diluted manually using ARCHITECT $i$ Multi-Assay Manual Diluent to concentrations ranging from $90 \%$ to $10 \%$ of the original $\mathrm{C}$-peptide value.

High-low dilution Five pairs of serum and urine specimens with high and low C-peptide concentrations were used to create pools with different concentrations. The reported concentrations were compared with the theoretical values and the $\%$ Recovery was calculated as $100 \times$ (mean observed concentration/mean expected concentration).

Spiking recovery Known concentrations $(0.05,0.24,1.20$, and $6.00 \mathrm{ng} / \mathrm{mL}$ ) of C-peptide were added to four human serum samples with endogenous concentrations ranging from $0.97 \mathrm{ng} / \mathrm{mL}$ to $16.33 \mathrm{ng} / \mathrm{mL}$ of C-peptide. For urine, 25, 50,100 , and $200 \mathrm{ng} / \mathrm{mL}$ of C-peptide were added to five urine samples with C-peptide values ranging from $6.12 \mathrm{ng} / \mathrm{mL}$ to $66.77 \mathrm{ng} / \mathrm{mL}$. The concentration of C-peptide was determined using the ARCHITECT C-Peptide assay and the resulting percent recovery calculated.

\section{Method comparison}

Two different commercially available C-peptide assays were compared with the ARCHITECT C-Peptide assay. Three hundred and ten serum specimens and 113 urine specimens from patients with abnormal insulin secretion were tested with the ARCHITECT C-Peptide and with the ADVIA Centaur C-Peptide assay (Siemens Healthcare Diagnostics Inc., Deerfield, IL, USA). In addition, 188 randomized serum and 96 urine specimens were analyzed with the ARCHITECT C-Peptide and with the Elecsys C-Peptide assay (Roche Diagnostics $\mathrm{GmbH}$, Mannheim, Germany). C-peptide concentrations were measured according to the manufacturer's instructions.

Slope and intercept were calculated using Least Squares and Passing-Bablok linear regression analyses (19), a linear regression method with no special assumptions regarding the distribution of the samples and measurement error. The correlation coefficient $(r)$ was calculated using the method of Pearson (20).

\section{General interference and specificity}

Interference and specificity were performed based on CLSI document EP7-A2 (21).

The following sample types were used for interference testing: 10 human pooled sera samples, 10 human pooled EDTA samples, and 10 urine samples. Five samples of each of the above-mentioned sample types were assayed following the addition of buffer containing no $\mathrm{C}$-peptide. The five remaining samples were spiked with different concentrations of $\mathrm{C}$-peptide that covered the entire assay range, and supplemented with potential interfering substances. Interference testing for rheumatoid factor (RF) was performed using five different sera and plasma samples.
Cross-reactivity was evaluated using five pools of human sera that were spiked with different concentrations of C-peptide. The C-peptide concentration covered the entire assay range and pools were supplemented with potential crossreactants.

\section{Blood collection tube types}

A total of nine different sample tube types were evaluated using a set of whole blood specimens. The blood specimens were tested neat and spiked with C-peptide. Percent recovery was calculated as $100 \times$ (concentration of sample type/concentration of serum in non-additive tube).

\section{Specimen stability}

Ten sera and 10 EDTA-plasma specimens, evaluated off the cell/clot and on the cell/clot, and 10 urine specimens were stored at $2^{\circ} \mathrm{C}-8^{\circ} \mathrm{C}$ and $15^{\circ} \mathrm{C}-30^{\circ} \mathrm{C}$ for $4,8,24$ and $48 \mathrm{~h}$ and at $15^{\circ} \mathrm{C}-30^{\circ} \mathrm{C}$ for 4,8 and $24 \mathrm{~h}$. Specimens off the cell/clot were also stored below $-10^{\circ} \mathrm{C}$ for $1,2,4,8$ and 12 weeks to determine long-term storage. Percent recovery was calculated as $100 \times\left(\right.$ Concentration $_{\text {time point } x} /$ Concentration $\left._{0 \mathrm{~h}}\right)$.

In addition, 10 sera, 10 EDTA-plasma specimens and 10 urine specimens were subjected to three freeze/thaw cycles to determine the number of cycles acceptable for each specimen type. Freeze/thaw was assessed with or without centrifugation following thawing. Percent recovery was calculated as $100 \times\left(\right.$ Concentration $_{\text {cyclex }} /$ Concentration $\left._{\text {unfrozen }}\right)$.

\section{Results}

\section{Expected values}

The distribution of results was non-parametric, showing a central 95th percentile distribution of C-peptide concentrations between $0.78 \mathrm{ng} / \mathrm{mL}$ and $5.19 \mathrm{ng} / \mathrm{mL}$ for serum, and between $8.20 \mathrm{ng} / \mathrm{mL}$ and $116.28 \mathrm{ng} / \mathrm{mL}$ for urine. In addition, the 95th percentile frequencies of absolute C-peptide contents in urine were calculated to range from $23.74 \mu \mathrm{g} / 24 \mathrm{~h}$ to $206.96 \mu \mathrm{g} / 24 \mathrm{~h}$ (Figure 1).

\section{Sensitivity}

In the range from $0.00 \mathrm{ng} / \mathrm{mL}$ to $0.05 \mathrm{ng} / \mathrm{mL}$, the analytical response of RLUs measured in the precision study showed discrimination between Calibrator $A$ and Calibrator B of $\sim 160 \mathrm{RLU}$ (mean standard value at $0 \mathrm{ng} / \mathrm{mL}$ ) to $\sim 1500 \mathrm{RLU}$ (mean standard value at $0.05 \mathrm{ng} / \mathrm{mL})$; a ratio of 9.3 .

Testing of multiple lots of the zero standard resulted in a LoB of $0.002 \mathrm{ng} / \mathrm{mL}$. The LoD was determined to be $0.01 \mathrm{ng} / \mathrm{mL}$. The value for the LoQ was 0.08 $\mathrm{ng} / \mathrm{mL}$, with a total error of $20 \%$. At $0.01 \mathrm{ng} / \mathrm{mL}$, the total error was $28 \%$ as was the highest observed total error in the study. At this level of total error, the LoO and LoD are at identical concentrations.

The analytical sensitivity was determined to be $0.002 \mathrm{ng} / \mathrm{mL}$. Functional sensitivity was $0.015 \mathrm{ng} / \mathrm{mL}$ at a $\% \mathrm{CV}$ of $11.2 \%$. Since a C-peptide concentration of $0.015 \mathrm{ng} / \mathrm{mL}$ represented the lowest concentration used in the study, the concentration of C-peptide 


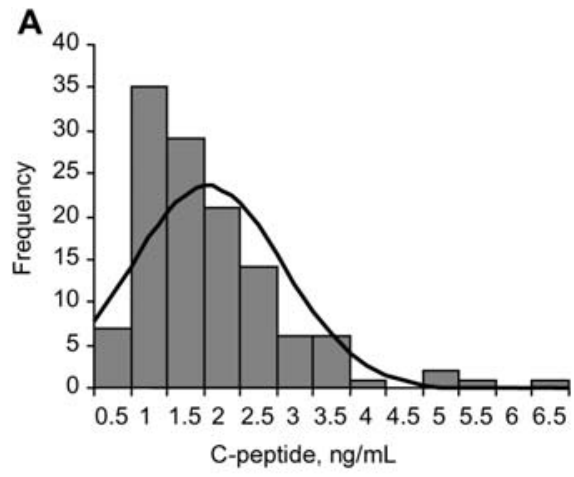

C

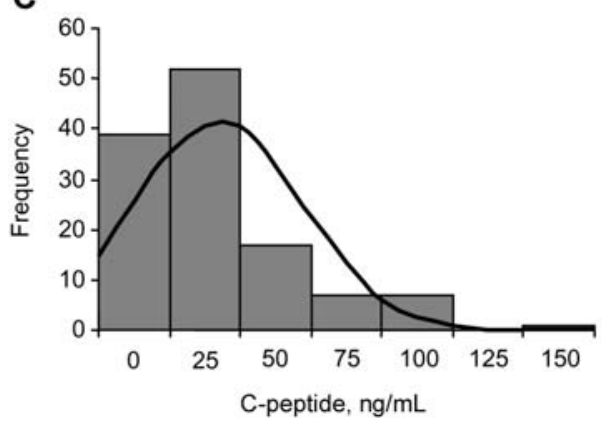

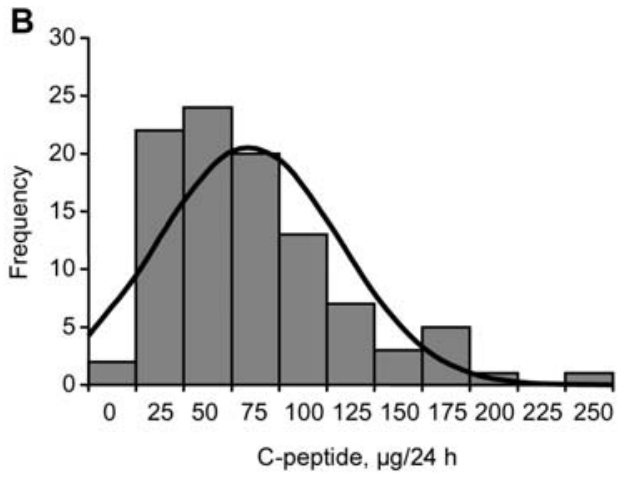

D

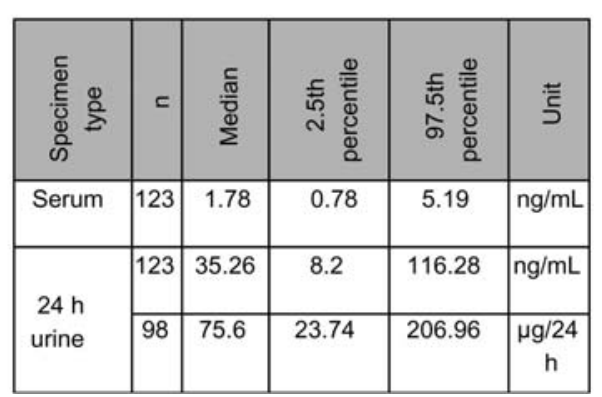

Figure 1 Non-parametric reference interval for serum $(\mathrm{ng} / \mathrm{mL})$ and urine $(\mu \mathrm{g} / 24 \mathrm{~h}$ and $\mathrm{ng} / \mathrm{mL})$.

(A-C) Frequency histograms for (A) serum specimens in $\mathrm{ng} / \mathrm{mL}$, (B) urine specimens in $\mu \mathrm{g} / 24 \mathrm{~h}$ and $(C)$ urine specimens in $\mathrm{ng} / \mathrm{mL}$. (D) Summarizes the median, the 2.5th and the 97.5 th percentile of the specimen populations.

showing a \%CV of $20 \%$ could not be determined (data not shown).

\section{Precision}

Precision results for the ARCHITECT C-Peptide assay are shown in Table 1. The \%CV across all controls and panels tested for within-run and total run ranged from $1.5 \%$ to $5.4 \%$ and from $2.1 \%$ to $6.5 \%$, respectively. The mean \%CV of all panels for within-run and total run was $2.4 \%$ and $3.4 \%$, respectively. The serum based controls had a mean \%CV of $2.1 \%$ for within-run and $2.5 \%$ for total run. For serum panels, the average $\% \mathrm{CV}$ for within-run and total run was $1.9 \%$ and $3.3 \%$, respectively. Urine panels showed a \%CV of $3.3 \%$ for within-run and $4.3 \%$ for total run.

\section{Recovery and linearity}

Dilution linearity Table 2 summarizes the results for linearity testing for the ARCHITECT C-Peptide assay.

Table 1 Summary of precision data.

\begin{tabular}{|c|c|c|c|c|c|c|c|c|}
\hline \multirow[t]{2}{*}{ Sample } & \multirow[t]{2}{*}{ Instrument } & \multirow{2}{*}{$\begin{array}{l}\text { Reagent } \\
\text { lot }\end{array}$} & \multirow[t]{2}{*}{$\mathrm{n}$} & \multirow{2}{*}{$\begin{array}{l}\text { Mean concentration, } \\
\mathrm{ng} / \mathrm{mL}\end{array}$} & \multicolumn{2}{|c|}{ Within-run } & \multicolumn{2}{|l|}{ Total } \\
\hline & & & & & SD & $\% \mathrm{CV}$ & SD & $\% \mathrm{CV}$ \\
\hline Low & 1 & 1 & 80 & 0.96 & 0.019 & 1.9 & 0.031 & 3.2 \\
\hline control & 2 & 2 & 80 & 0.96 & 0.030 & 2.8 & 0.030 & 3.2 \\
\hline Medium & 1 & 1 & 80 & 3.86 & 0.060 & 1.6 & 0.081 & 2.1 \\
\hline control & 2 & 2 & 80 & 3.96 & 0.090 & 2.3 & 0.100 & 2.5 \\
\hline High & 1 & 1 & 80 & 17.22 & 0.308 & 1.8 & 0.359 & 2.1 \\
\hline control & 2 & 2 & 80 & 17.34 & 0.340 & 1.9 & 0.360 & 2.1 \\
\hline Serum & 1 & 1 & 80 & 0.69 & 0.014 & 2.0 & 0.027 & 3.9 \\
\hline panel 1 & 2 & 2 & 80 & 0.75 & 0.015 & 2.0 & 0.030 & 4.0 \\
\hline Serum & 1 & 1 & 80 & 3.46 & 0.060 & 1.7 & 0.118 & 3.4 \\
\hline panel 2 & 2 & 2 & 80 & 3.60 & 0.069 & 1.9 & 0.099 & 2.8 \\
\hline Serum & 1 & 1 & 80 & 14.63 & 0.225 & 1.5 & 0.404 & 2.8 \\
\hline panel 3 & 2 & 2 & 80 & 14.63 & 0.350 & 2.4 & 0.393 & 2.7 \\
\hline Urine & 1 & 1 & 80 & 8.45 & 0.239 & 2.8 & 0.316 & 3.7 \\
\hline panel 1 & 2 & 2 & 80 & 8.66 & 0.469 & 5.4 & 0.567 & 6.5 \\
\hline Urine & 1 & 1 & 80 & 44.93 & 0.838 & 1.9 & 1.170 & 2.6 \\
\hline panel 2 & 2 & 2 & 80 & 46.72 & 1.511 & 3.2 & 2.052 & 4.4 \\
\hline Urine & 1 & 1 & 80 & 140.51 & 2.856 & 2.0 & 4.763 & 3.4 \\
\hline panel 3 & 2 & 2 & 80 & 146.08 & 6.881 & 4.7 & 7.141 & 4.9 \\
\hline
\end{tabular}


Table 2 Linearity of diluted serum and urine specimens.

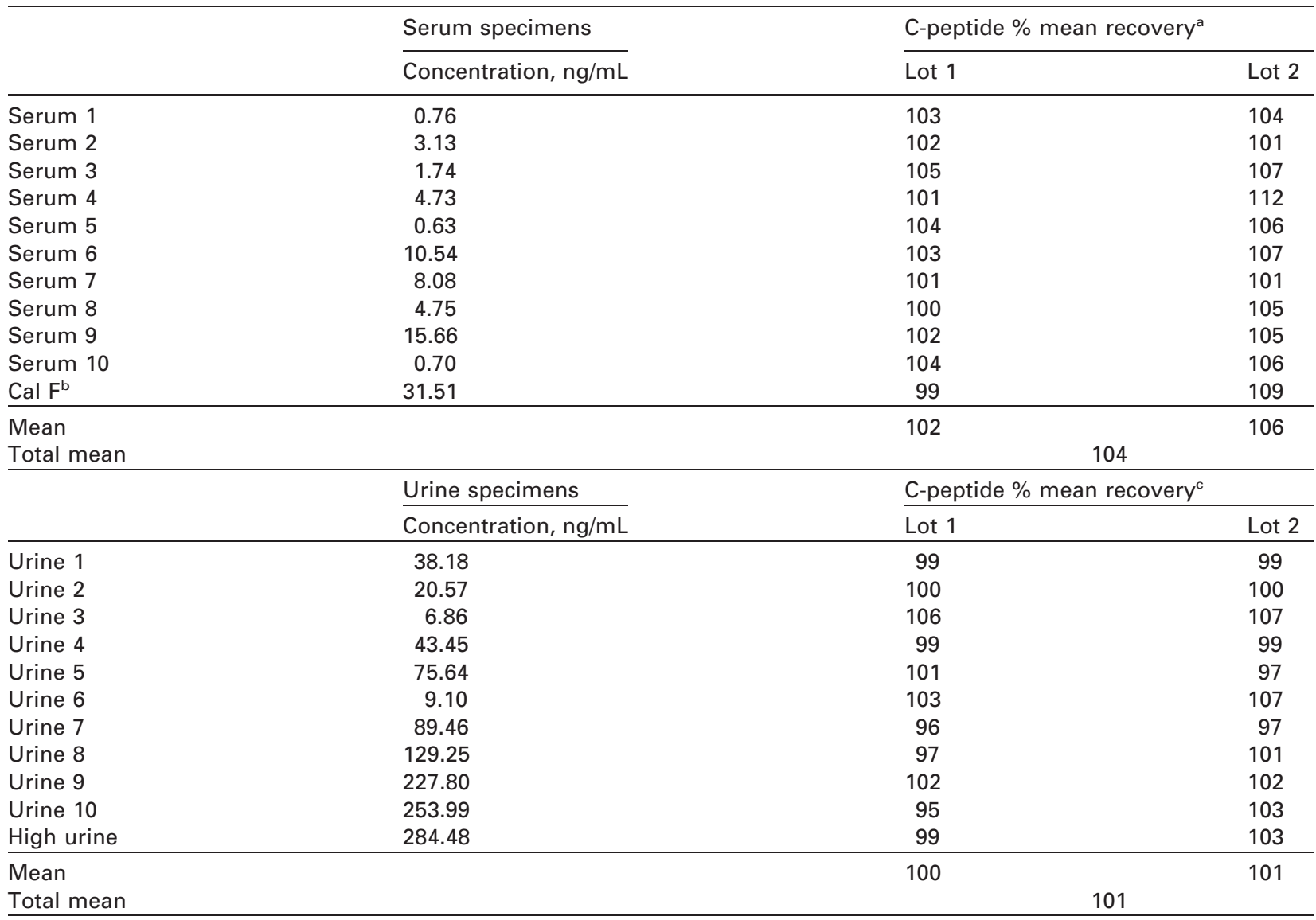

a Mean percent recovery of serum specimens, diluted to $50 \%$ of their original concentration. ${ }^{b}$ Calibrator $F$, diluted to $10 \%$ of its original concentration. 'Mean \% recovery for urine specimens, diluted down to $10 \%$ of their original concentration are shown.

Linearity for serum specimens could be demonstrated in dilutions ranging from $100 \%$ to $50 \%$ of the original concentration. When samples were further diluted from $50 \%$ to $10 \%$ of their original concentrations, two out of 10 samples gave a mean recovery higher than $115 \%$ (data not shown).

Using urine specimens, the linearity of the ARCHITECT C-Peptide assay was demonstrated in the dilution range from $100 \%$ to $10 \%$ of the original concentration (Table 2).

High-low dilution C-peptide values measured in specimens with high concentrations that were progressively diluted with specimens containing low Cpeptide concentrations were found to be very close to the expected values. The mean percent recovery for serum specimens ranged from $95.4 \%$ to $102.7 \%$, and for urine specimens the percent recovery ranged from $97.5 \%$ to $113.6 \%$ (data not shown).

Recovery in spiked samples The percent recovery obtained with the ARCHITECT C-Peptide assay in serum specimens and in urine specimens ranged from $91.2 \%$ to $100.9 \%$ (mean $96.2 \%$ ) and from $98.9 \%$ to $101.2 \%$ (mean 99.8\%), respectively (data not shown).

\section{Method comparison}

Specimens from patients exhibiting abnormal insulin secretion were analyzed side-by-side with the ARCHITECT C-Peptide and the ADVIA Centaur C-Peptide assay. In this study, the concentrations in serum specimens $(\mathrm{n}=310)$ ranged from $0.01 \mathrm{ng} / \mathrm{mL}$ to 23.31 $\mathrm{ng} / \mathrm{mL}$ and from $0.62 \mathrm{ng} / \mathrm{mL}$ to $23.03 \mathrm{ng} / \mathrm{mL}$, respectively (Figure 2A). The concentrations in urine specimens $(n=113$ ) ranged from $1.34 \mathrm{ng} / \mathrm{mL}$ to 286.64 $\mathrm{ng} / \mathrm{mL}$ and from $0.92 \mathrm{ng} / \mathrm{mL}$ to $261.65 \mathrm{ng} / \mathrm{mL}$, respectively (Figure 2B). Serum specimens analyzed by Passing-Bablok and by Least Squares revealed a slope of 1.02 and 0.99 , respectively, and a correlation coefficient of 0.99 . Urine specimens analyzed by Passing-Bablok and by Least Squares revealed slopes of 1.15 and 1.07 , respectively, and a correlation coefficient of 0.99 .

In a separate method comparison study, randomized samples were tested in parallel with the ARCHITECT C-Peptide assay and the Elecsys C-Peptide assay. The concentrations of the serum specimens ( $\mathrm{n}=188$ ) ranged from $0.01 \mathrm{ng} / \mathrm{mL}$ to $25.75 \mathrm{ng} / \mathrm{mL}$ and from $0.06 \mathrm{ng} / \mathrm{mL}$ to $32.61 \mathrm{ng} / \mathrm{mL}$, respectively. Concentrations in urine specimens $(n=96)$ ranged from $0.11 \mathrm{ng} / \mathrm{mL}$ to $283.85 \mathrm{ng} / \mathrm{mL}$ and from $0.09 \mathrm{ng} / \mathrm{mL}$ to $250.89 \mathrm{ng} / \mathrm{mL}$, respectively (data not shown). Serum 
A

ARCHITECT vs. ADVIA Centaur

Passing-Bablok fit - serum specimens

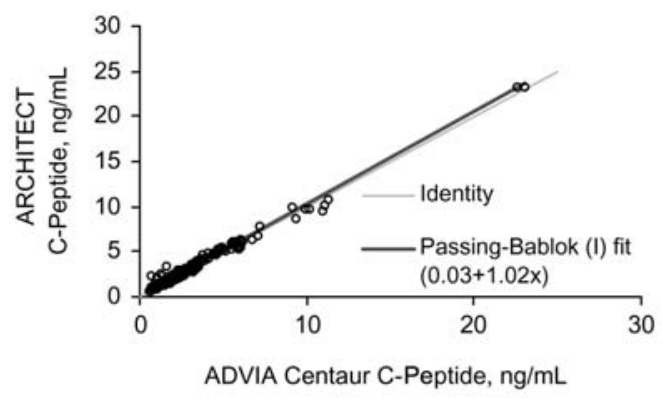

C

ARCHITECT vs. ADVIA Centaur Difference Plot - serum specimens

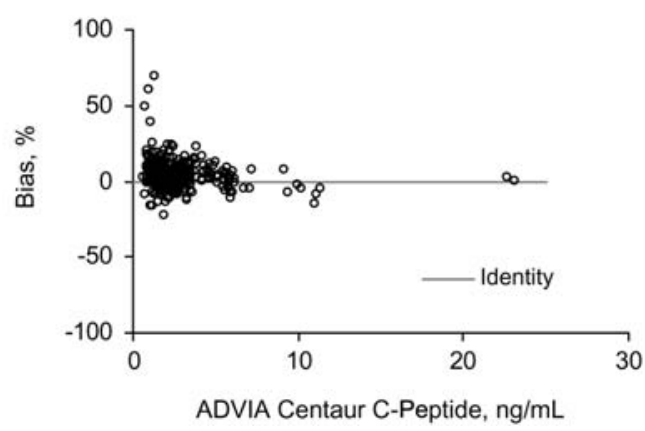

B ARCHITECT vs. ADVIA Centaur

Passing-Bablok fit - urine specimens

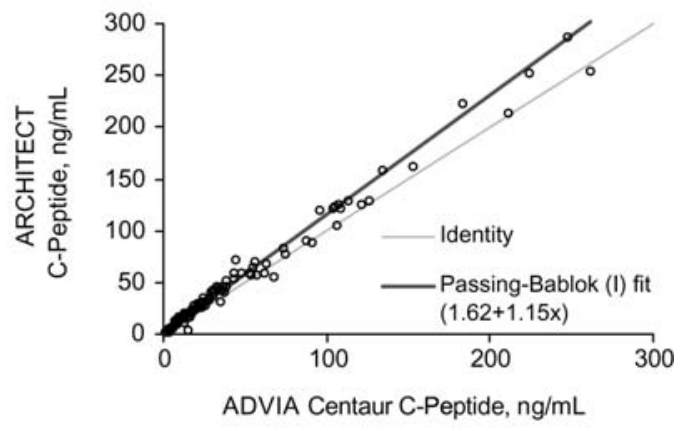

D

ARCHITECT vs. ADVIA Centaur Difference Plot - urine specimens

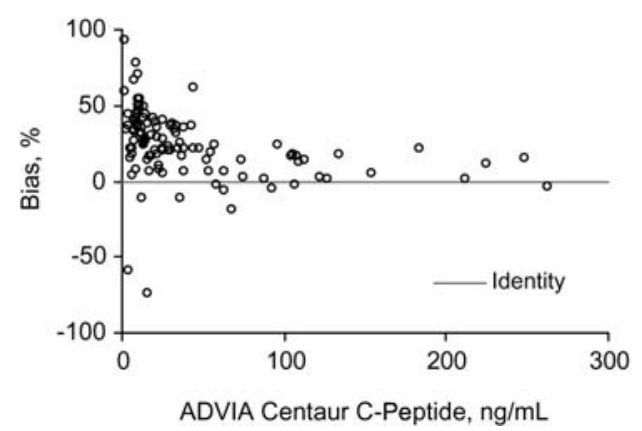

Figure 2 Method comparison.

ARCHITECT C-Peptide assay vs. ADVIA Centaur C-Peptide assay. In (A) and (C) Passing-Bablok and difference plot between the two methods are shown for serum specimens, (B) and (D) display Passing-Bablok and difference plot for urine specimens. The thin line indicates identity between the two methods, the thick line in (A) and (B) indicates the Passing-Bablok fit.

specimens analyzed by Passing-Bablok and by Least Squares revealed slopes of 0.76 and 0.78 , respectively, intercepts of -0.09 and -0.19 , respectively, and a correlation coefficient of 0.99 . Urine specimens analyzed by Passing-Bablok and by Least Squares revealed slopes of 1.12 and 1.12 , respectively, intercepts of -1.74 and -1.48 , respectively, and a correlation coefficient of 1.00 (data not shown).

\section{General interference and specificity}

Table 3 summarizes the results of interference and cross-reactivity testing, and the concentrations used for interferences and cross-reactive substances.

In the ARCHITECT C-Peptide assay, the percent mean recovery of serum specimens spiked with hemoglobin, bilirubin, triglycerides, protein, RF, human anti-mouse antibodies (HAMA), and red blood cells ranged from $91.9 \%$ to $102.3 \%$.

For urine specimens, the percent mean recovery following addition of creatinine, urea, glucose, $\mathrm{NaCl}$, acetone and leucocytes ranged from $94.6 \%$ to $100.7 \%$, suggesting no significant interference with the substances we evaluated.

The percent cross-reactivity, estimated after adding different putative cross-reactive compounds, was below $0.01 \%$ (observed values vs. expected values) for human insulin, glucagon, secretin, and somato-
medin-C (IGF-1). Human proinsulin showed $12.80 \%$ cross-reactivity.

\section{Blood collection tube types}

The mean percent recovery for eight of the nine different sample tube types we evaluated ranged from $92.0 \%$ to $101.6 \%$, when compared with serum that was obtained without additives. For sodium-citrate tubes, the mean recovery was at $86.1 \%$. The nonspiked sodium-citrate samples showed a mean recovery of $80 \%$. Thus, this sample type is not recommended for use in the ARCHITECT C-Peptide assay (data not shown).

\section{Specimen stability}

The percent recovery for C-peptide in serum and plasma specimens that remained on the cell/clot for up to $24 \mathrm{~h}$ storage at $15^{\circ} \mathrm{C}-30^{\circ} \mathrm{C}$ ranged from $87.3 \%$ to $99.0 \%$ and from $93.3 \%$ to $97.2 \%$, respectively. The percent recovery for $\mathrm{C}$-peptide in serum and plasma that was maintained off the cell/clot for up to $24 \mathrm{~h}$ and stored at $15^{\circ} \mathrm{C}-30^{\circ} \mathrm{C}$ ranged from $96.4 \%$ to $96.7 \%$ and from $97.1 \%$ to $100.6 \%$, respectively. The percent recovery of $\mathrm{C}$-peptide in serum and plasma specimens after storage up to $48 \mathrm{~h}$ at $2^{\circ} \mathrm{C}-8^{\circ} \mathrm{C}$ ranged from $96.5 \%$ to $101.0 \%$ and from $96.2 \%$ to $100.0 \%$, respectively. There was no difference in percent recovery 
Table 3 General interference in serum and urine and results of cross-reactivity.

\begin{tabular}{|c|c|c|}
\hline Potentially interfering substances & Concentration (SI unit) & $\%$ Mean recovery \\
\hline \multicolumn{3}{|l|}{ Interference in serum } \\
\hline Hemoglobin & 500 mg/dL (50 mmol/L) & 101.8 \\
\hline Bilirubin & $20 \mathrm{mg} / \mathrm{dL}(1.17 \mu \mathrm{mol} / \mathrm{L})$ & 99.6 \\
\hline Triglycerides & $5000 \mathrm{mg} / \mathrm{dL}$ (442478 mmol/L) & 102.3 \\
\hline Protein (human albumin) & 12 g/dL (120 g/L) & 91.9 \\
\hline Rheumatoid factor & $100 \mathrm{IU} / \mathrm{mL}$ & 93.1 \\
\hline Human anti-mouse antibodies & $1000 \mathrm{ng} / \mathrm{mL}$ & 99.7 \\
\hline Red blood cells & $0.4 \% \mathrm{v} / \mathrm{v}$ & 100.5 \\
\hline \multicolumn{3}{|l|}{ Interference in urine } \\
\hline Creatinine & $600 \mathrm{mg} / \mathrm{dL}(6.79 \mu \mathrm{mol} / \mathrm{L})$ & 100.7 \\
\hline Urea & 6 g/dL (999 mmol/L) & 94.6 \\
\hline Glucose & 300 mg/dL (5405 mmol/L) & 100.1 \\
\hline $\mathrm{NaCl}$ & 6 g/dL (1027 mmol/L) & 95.1 \\
\hline Acetone & $6 \mathrm{mg} / \mathrm{dL}(1.033 \mathrm{mmol} / \mathrm{L})$ & 100.1 \\
\hline Leukocytes & 20 cells $/ \mu L$ & 100.1 \\
\hline Cross-reactant & Concentration, ng/mL & $\%$ Cross-reactivity \\
\hline \multicolumn{3}{|l|}{ Cross reactivity } \\
\hline Human insulin & 8660 & Not detectable \\
\hline Glucagon & 10,000 & Not detectable \\
\hline Human proinsulin & 100 & 12.80 \\
\hline Secretin & 15,000 & Not detectable \\
\hline Somatomedin-C (IGF-1) & 1000 & Not detectable \\
\hline
\end{tabular}

regardless of whether specimens were stored on or off the cell/clot. Percent recovery following long-term storage of up to 12 weeks at $-10^{\circ} \mathrm{C}$ ranged from $95.6 \%$ to $99.6 \%$.

The percent recovery observed after as many as three freeze/thaw cycles ranged from $99.4 \%$ to $101 \%$ for serum, plasma and urine specimens. The percent recovery for thawed specimens were comparable, regardless of whether specimens were centrifuged or not centrifuged prior to analysis following thawing (data not shown).

\section{Discussion}

The most appropriate measure of endogenous insulin secretion and $\beta$-cell function is analysis of $C$-peptide using standardized conditions (22). The performance requirements for a high-quality $\mathrm{C}$-peptide assay are good sensitivity for the analyte, combined with low statistical dispersion (\%CV). In addition, low crossreactivity (specificity) and negligible effects from interferences are desirable, as well as the ability to measure the analyte in different matrices such as serum, plasma and urine using a high-throughput and fully automated platform.

The ARCHITECT C-Peptide assay fulfills the above stated requirements combining good precision, which is well within the desirable specifications for serum specimens $(23,24)$, and good limits of detection as demonstrated in our studies on analytical sensitivity. The highest observed value for total error of $28 \%$ was unexpected. This probably was due to the samples used for determination of the LoO being highly-diluted ( $>50 \%$ of their of their original concentration) (24). The assay was highly specific for C-peptide as demonstrated by lack of cross-reactivity with human insulin, glucagon, secretin, and somatomedin- $\mathrm{C}$ and by lack of interference from potential interfering sub- stances. The assay can be performed using a variety of blood collection tube types and matrices including plasma, serum and urine. Operational efficiency is provided by ready to use reagents, calibrators and controls, and the option to measure C-peptide together with other diabetes markers such as insulin, glucose and hemoglobin $A_{1 c}$ (25).

Linearity studies revealed that serum samples can be diluted $50 \%$ using an equal volume of ARCHITECT $i$ Multi-Assay Manual Diluent and sample. A dilution of $50 \%$ should be sufficient since C-peptide concentrations greater than the upper limit of the assay (30 $\mathrm{ng} / \mathrm{mL}$ ) should be seen rarely.

Good correlation and minimum bias was observed in the method comparison study using serum samples when compared with the ADVIA Centaur C-Peptide assay. Good correlation $(r=0.99)$ and a relatively low slope of 0.78 (Least Squares) was observed in the method comparison study using serum measured with the Elecsys. Like the ARCHITECT C-Peptide assay, the ADVIA Centaur C-Peptide assay and the Elecsys C-Peptide assay are standardized using the same international standard, WHO code $84 / 510$. Thus, the reason for the low slope observed using serum samples in the comparison between the ARCHITECT and the Elecsys C-Peptide assays cannot be attributed to different standards being used. However, it might be related to different assay formats and the antibodies used (26).

In conclusion, our studies show that the ARCHITECT C-Peptide assay demonstrates optimal analytical performance and good correlation on the target population tested.

\section{Trademark notes}

ARCHITECT C-Peptide assay and ARCHITECT $i$ MultiAssay Manual Diluent are trademarks of Abbott Lab- 
oratories in various jurisdictions. All other trademarks are the property of their respective owners.

\section{Acknowledgements}

The authors thank the following investigators and technicians for their participation in this study or for providing specimens: Ralf Jantos, Partnerschaftspraxis für Laboratoriumsmedizin und Mikrobiologie (Hameln, Germany), Canisius-Wilhelmina Hospital (CWZ, Nijmegen, The Netherlands), Centre de Transfusió I Banc de Teixits de Catalunya (Barcelona, Spain), and Biobanc (Hospital Sant Joan, Reus, Spain), and all participating technical personnel at Future Diagnostics, The Netherlands and Biokit, Spain.

\section{References}

1. Oyer PE, Cho S, Peterson JD, Steiner DF. Studies on human proinsulin. Isolation and amino acid sequence of the human pancreatic C-peptide. J Biol Chem 1971; 246:1375-86.

2. Steiner DF. The proinsulin C-peptide - a multirole model. Exp Diabesity Res 2004;5:7-14.

3. Wahren J, Ekberg K, Johansson J, Henriksson M, Pramanik $A$, Johansson $B L$, et al. Role of $C$-peptide in human physiology. Am J Physiol Endocrinol Metab 2000;278:E759-68.

4. Dodson G, Steiner D. The role of assembly in insulin's biosynthesis. Curr Opin Struct Biol 1998;8:189-94.

5. Rubenstein AH, Clark JL, Melani F, Steiner DF. Secretion of proinsulin C-peptide by pancreatic beta cells and its circulation in blood. Nature 1969;224:697-9.

6. Horwitz DL, Starr JI, Mako ME, Blackard WG, Rubenstein $\mathrm{AH}$. Proinsulin, insulin, and C-peptide concentrations in human portal and peripheral blood. J Clin Invest 1975;55:1278-83.

7. Polonsky KS, Licinio-Paixao J, Given BD, Pugh W, Rue $P$, Galloway J, et al. Use of biosynthetic human C-peptide in the measurement of insulin secretion rates in normal volunteers and type I diabetic patients. J Clin Invest 1986;77:98-105.

8. Hendriksen C, Faber OK, Drejer J, Binder C. Prevalence of residual B-cell function in insulin-treated diabetics evaluated by the plasma C-peptide response to intravenous glucagons. Diabetologia 1977;13:615-9.

9. Hoekstra JB, Van Rijn HJ, Thijssen JH, Erkelens DW. Cpeptide reactivity as a measure of insulin dependency in obese diabetic patients treated with insulin. Diabetes Care 1982;5:585-91.

10. Scarlett JA, Mako ME, Rubenstein AH, Blix PM, Goldman J, Horwitz DL, et al. Factitious hypoglycemia. Diagnosis by measurement of serum C-peptide immunoreactivity and insulin-binding antibodies. Engl J Med 1977;297: 1029-32.

11. Vezzosi D, Bennet A, Fauvel J, Caron P. Insulin, C-peptide and proinsulin for the biochemical diagnosis of hypogly- caemia related to endogenous hyperinsulinism. Eur $\mathrm{J}$ Endocrinol 2007;157:75-83.

12. Greco AV, Crucitti F, Ghirlanda G, Manna R, Altomonte $L$, Rebuzzi AG, et al. Insulin and glucagon concentrations in portal and peripheral veins in patients with hepatic cirrhosis. Diabetologia 1979;17:23-8.

13. Bristow AF, Das RE. WHO international reference reagents for human proinsulin and human insulin C-peptide. J Biol Stand 1988;16:179-86.

14. Analyse-it for Microsoft Excel (version 1.73 or higher) Analyse-it Software, Ltd. http://www.analyse-it.com/; 2007.

15. SAS (version 6.12 or higher). 2006. Cary, NC: SAS Institute.

16. Clinical and Laboratory Standards Institute. How to define and determine reference intervals in the clinical laboratory: approved guideline, 2nd ed. CLSI Document C28-A2. Wayne, PA: Clinical and Laboratory Standards Institute, 2000.

17. Clinical and Laboratory Standards Institute. Protocols for determination of limits of detection and limits of quantitation: approved guideline. CLSI Document EP17-A. Wayne, PA: Clinical and Laboratory Standards Institute, 2004.

18. Clinical and Laboratory Standards Institute. Evaluation of precision performance of quantitative measurement methods: approved guideline, 2nd ed. CLSI Document EP5-A2. Wayne, PA: Clinical and Laboratory Standards Institute, 2004.

19. Passing HA, Bablok W. New biometrical procedure for testing the equality of measurements from two different analytical methods. J Clin Chem Clin Biochem 1983;21: 709-20.

20. Sheskin DJ. Handbook of parametric and nonparametric statistical procedures, 4th ed. Boca Raton: Chapman and Hall, 2007; 1219 pp.

21. Clinical and Laboratory Standards Institute. Interference testing in clinical chemistry: approved guideline, 2 nd ed. CLSI Clinical and Laboratory Standards Institute. Interference Testing Document EP7-A2. Wayne, PA: Clinical and Laboratory Standards Institute, 2005.

22. Palmer JP, Fleming GA, Greenbaum CJ, Herold KC, Jansa LD, Kolb H, et al. C-peptide is the appropriate outcome measure for type 1 diabetes clinical trials to preserve $\beta$-cell function. Diabetes 2004;53:250-64.

23. Ricós C, Arbós MA. Quality goals for hormone testing. Ann Clin Biochem 1990;27:353-8.

24. Ricós C, Alvarez V, Cava F, García-Lario JV, Hernández A, Jiménez CV, et al. Current databases on biological variation: pros, cons and progress. Scand J Clin Lab Invest 1999;59:491-500.

25. Park SW, Ihm SH, Yoo HJ, Park JY, Lee KU. Differential effects of ambient blood glucose level and degree of obesity on basal serum C-peptide level and the C-peptide response to glucose and glucagon in non-insulindependent diabetes mellitus. Diabetes Res Clin Pract 1997;37:165-71.

26. Little RR, Rohlfing CL, Tennill AL, Madsen RW, Polonsky KS, Myers GL, et al. Standardization of C-peptide measurements. Clin Chem 2008;54:1023-6. 